\title{
København-Kairo, tur-retur: En sikkerhedsteori møder revolutionen
}

\begin{abstract}
Maja Touzari Janesdatter Greenwood projektkoordinator på CASTs Securitizing Arab Development projekt og specialestuderende ved ToRS, København Universitet; E-mail: majatouzari@gmail. com

Ole Wæver professor i International Politik, Institut for Statskundskab, København Universitet og leder af Centre for Advanced Security Theory, E-mail: OW@ifs.ku.dk
\end{abstract}

Sikkerhedsliggørelsesteorien er en vestligt funderet teori, som blev sat på spidsen, da den pludselig befandt sig midt i den egyptiske revolution. Dette førte til overvejelser omkring, hvordan sikkerhedsliggørelsesteorien kan bruges i en mellemøstlig kontekst og måske endda bidrage til en demokratiseringsproces; hvordan den egyptiske revolution ser ud i Københavnerskolens optik, samt hvad mødet med mellemøstlige forhold og en egyptisk revolution kan betyde for Københavnerskolens egen fortsatte udvikling af teorien.

Sikkerhedsliggørelsesteorien er en vestligt funderet teori - måske endda ganske lokalt forankret, som dens tilnavn 'Københavnerskolen' antyder. Teorien har godt nok fundet anvendelse på cases verden rundt, men der har også været hørbar kritik af teorien for at være uegnet til ikkevestlige situationer. $^{2}$

$\mathrm{Da}$ Centre for Advanced Security Theory (CAST), som baserer en stor del af sin forskning på Københavnerskolen, i 2010 indgik i et samarbejde med det Dansk Egyptiske Dialog Institut (DEDI) og al-Ahram Centre for Political and Strategic Studies (ACPSS) i Kairo, mødte Københavnerskolen ikke kun en mellemøstlig dagsorden, men befandt sig også pludselig midt i det arabiske forårs oprør, en dobbelt udfordring for teorien. Fra starten var det klart, at vi ikke kun indgik i en teoretisk afklaring af, i hvilken udstrækning sikkerhedsliggørelsesteorien kunne applikeres af lokale teoretikere og praktikere i en mellemøstlig kontekst, men også i et politisk projekt med mulighed for at påvirke udvidelsen af sikkerhedsbegrebet i en mere demokratiserende retning. Det politiske blev sat på spidsen, da Egypten pludselig befandt sig midt i en revolution. Det blev vigtige teoridebatter så også, for sikkerhedsliggørelse under en revolution rammer midt ned $i$ et af de hotteste spørgsmål om teorien: dens politikbegreber (Gad \& Petersen 2011).

Denne artikel vil først præsentere det samarbejde, som førte Københavnerskolen til Kairo under revolutionen samt den forudgående mellemøstlige debat om udvidelse af sikkerhedsbegrebet. Derefter vil vi gennemgå erfaringerne med de konkrete workshops for at etablere en empirisk platform, hvorfra vi slutteligt vil reflektere på tre forskellige problemstillinger: Kan sikkerhedsliggørelsesteorien bruges i Mellemøsten og måske endda bidrage til demokratisering; hvordan ser den egyptiske revolutionære situation ud i Københavnerskolens optik; samt hvad har 'rejseoplevelsen' betydet for Københavnerskolens egen fortsatte udvikling af teorien. Denne artikel vender altså både sit blik udad, på den egyptiske revolution, og indad, hvor mellemøstlige forhold og den egyptiske revolution udfordrer teorien.

DEDI er et Kairo-baseret projekt under Danmarks 'Arabiske Initiativ', som søger at styrke lokale reformprocesser gennem politisk og kulturel dialog mellem Danmark og Egypten. DEDI faciliterer samarbejdsprojekter for journalister, gadekunstnere, kvindeorganisationer, forskere og mange flere. Som en del af dette bragte DEDI CAST og ACPSS sammen i projektet Securitizing Arab Development. ACPSS er et forskningscenter, som i 1968 blev etableret inden for den indflydelsesrige al-Ahram mediekoncernen. ACPSS har især arbejdet med regionale konflikter, interaktion mellem Mellemøsten og Vesten 
samt politiske, militære, økonomiske og sociale forhold i Egypten. ACPSS har rådgivet den tidligere egyptiske regering på flere strategiske områder, ikke mindst: sikkerhed. Derfor ønskede ACPSS også, som en konsekvens af en voksende akademisk debat om en udvidelse af det traditionelle sikkerhedsbegreb og Egyptens voksende erfaring af utraditionelle sikkerhedstrusler, at undersøge det udvidede sikkerhedsbegreb i en arabisk ${ }^{3}$ kontekst.

Den teoretiske interesse set fra København var i høj grad at opleve udmøntningen, 'mens det tog form' af en særlig regional variant af begrebsudvidelsen. Praktiskpolitisk lå udfordringen $\mathrm{i}$ at udnytte teorikendskabet og viden om andre regioners erfaringer til at indgå $i$ et samarbejde, hvor det afgørende ord nødvendigvis ville ligge hos vores partnere. 'Sikkerhed' er - jf. Københavnerskolen - så 'farligt' et begreb, at der kan være ganske meget på spil politisk, når man udvider i én form frem for en anden; så selv en lille påvirkning her kan bidrage til regionens demokratisering og politisering.

Hvor den arabiske verden tidligere var fokuseret på klassisk, militær sikkerhed, konstaterede DEDI's daværende direktør Rasmus Boserup, at det begyndte at blive muligt at tale bredere om sikkerhed. I nøglelandet Egypten var og er militæret så centralt, at ikke-militær sikkerhed havde haft svære vilkår. Alligevel taltes stadig mere om 'ikke-traditionelle trusler', sågar ' 'human security'. I april 2007 diskuterede FN's sikkerhedsråd for første gang sikkerhedsmæssige konsekvenser af klimaforandringer, i 2008 arrangerede Den Arabiske Kvindeorganisation en større konference med fokus på kvinder og human security, og Arab Human Development rapporten fra 2009 debatterede human security. Sidstnævnte rapport, der er den femte i en bemærkelsesværdig serie af rapporter fra selvstændige arabiske intellektuelle, fokuserer på human security-begrebet som ramme for at håndtere udfordringer for arabiske landes udvikling. Rapporten argumenterer, at de arabiske landes fokus på stats-sikkerhed er foregået på bekostning af borgernes individuelle sikkerhed og paradoksalt har ført til, at man har overset trusler mod national og international sikkerhed. Der var derfor et behov for at bevæge sig væk fra det traditionelle statscentrerede sikkerhedsbegreb til fordel for transnationalt samarbejde og fokus på borgernes sikkerhed fra en lang række utraditionelle sikkerhedstrusler såsom organiseret kriminalitet, klimaforandringer og sociopolitisk vold.

I forlængelse heraf tog Boserup initiativ til samarbejdet Securitizing Arab Development bestående af en serie konferencer og udgivelser, som med inddragelse af Københavnerskolens sikkerhedsteori diskuterede en mulig udvidelse af sikkerhedsbegrebet i den arabiske verden med det formål, at styrke udviklingen af både begrebsapparat og effektive strategier i forhold til nyere sikkerhedstrusler.
Da emnet repræsenterer mange og stærke dagsordener i regionen, inkluderede konferenceserien danske og egyptiske akademikere og praktikere på en bred vifte af områder. Hensigten var således ikke at promovere en bestemt strategi for arabisk sikkerhedstænkning, men at engagere Mellemøstens politikere, akademikere og praktikere i en kritisk debat for at klarlægge begreber og prioriteter med henblik på at finde en regional samarbejdsløsning inde fra regionen selv. Denne opgave ændrede naturligt nok karakter, da det egyptiske samfund pludselig begyndte at ændre sig hastigt og overraskende.

Københavnerskolen er en teoretisk linje inden for sikkerhedsstudier, som er udviklet af Barry Buzan, Ole Wæver m.fl. - i dag med CAST som en de teoretiske bastioner. Københavnerskolen foreslår, at sikkerhed som begreb ikke kun skal forstås som militær-politiske relationer mellem stater, men også kan praktiseres i forhold til andre referent objects. Et sikkerhedsemne defineres derfor ikke ud fra, hvorvidt referenten eller trusselstypen lever op til ydre givne kriterier fra en teori, men ud fra den talehandlingssituation som det befinder sig indenfor; det er ved at beskrive noget som et sikkerhedsemne, at det bliver et, og deri ligger handlingen (Wæver 1995). Således kan en sikkerhedsliggørende aktør flytte emnet ud af normale politiske rammer og rekonstruere det som et undtagelsesspørgsmål og legitimere ekstraordinære (potentielt udemokratiske) handlingsmuligheder. At sikkerhedsliggøre er altså at hævde, at nogets fortsatte eksistens er truet $\mathrm{i}$ en grad og form, så det kan afhænge af - og dermed legitimerer - ekstraordinære tiltag (Buzan et al. 1998, 24). Københavnerskolens syn på denne sikkerhedsliggørelsesproces er grundliggende kritisk, da den ser det som en manglende evne til at håndtere et emne inden for de normale politiske rammer $-\mathrm{i}$ bedste fald et valg af et mindre onde, men ikke 'jo mere sikkerhed, jo bedre'.

Sikkerhedspolitikken er en form for politisk trumf, et særligt træk, der skubber afvejninger og hensyn til side og erstatter dem af en angivelig nødvendighed for at 'afværge truslen'. Dermed bliver sikkerhedspolitik ikke kun styrende for håndteringen af dens konkrete emner, men bliver også en generel slagmark for fastlæggelse af politikkens grænser og vilkår og dermed af ganske vidtgående betydning for et samfund, især i brydningstider.

Blandt grunde til at anfægte teoriens anvendelighed uden for Vesten er den mest udbredte - men desværre fejlagtige - at teorien forudsætter liberal-demokratiske vilkår, hvilket overser, at sikkerhedsliggørelsens afpolitiserende effekter forstås relativt og derfor optræder i både demokratiske og udemokratiske samfund. En 'bedre' bekymring har været, at stat og samfund ofte er mindre tæt koblet, og central politik gennemtrænger sjældnere samfundet i den tredje verden (jf. note 2). Stærkest står 
Fig. 1: Udvidelsens politiske kampe

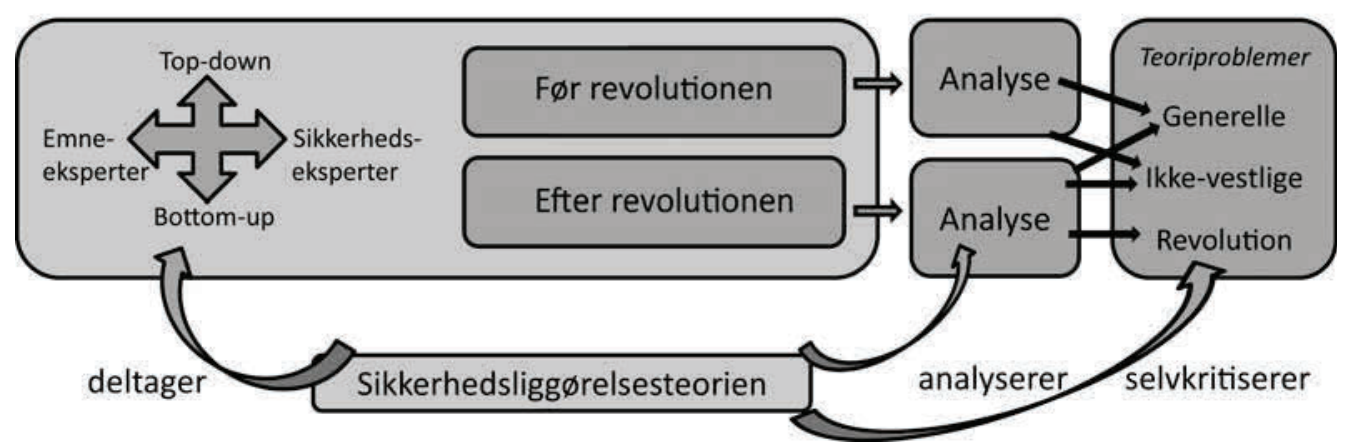

nok den generelle postkoloniale kritik, at vi bruger vestlige begreber, hvor kolonialisering og afkolonialisering har skabt helt andre realiteter (Chatterjee 2004).

Mindre bemærket i den akademiske debat er en markant regional variation i udvidelsen af sikkerhedsbegrebet, hvor forskellige kampe og politiske dagsordener investeres i udvidelsen i forskellige regioner. Der er typisk nogle lokalt forankrede centrale akser og 'projekter' på spil politisk, når 'udvidelse' ruller ind over en region (Wæver n.d.), hvorfor vi kiggede særligt opmærksomt efter, hvilke styrende spørgsmål og interesser der var på spil i den arabiske case.

Artiklen forløber i to lag. På ét plan er fokus den egyptiske behandling - akademisk og politisk - af sikkerhedsbegrebet for at indoptage 'nye trusler'. Her er emnet 'sikkerhedsbegrebets udvidelse' og 'nye trusler', ikke sikkerhedsliggørelsesteori. Egypten havde - trods alt! - ikke en bred debat for og imod Københavnerskolen, men en diskussion for og imod og hvordan omkring sikkerhedsbegrebets eventuelle udvidelse. Vi fik mulighed for at deltage i den proces. Som deltager var vi i høj grad selv 'styret' af sikkerhedsliggørelsesteori, og den teori opstod i sin tid som en metarefleksion over udvidelsens dilemmaer. Sikkerhedsliggørelsesteori optræder på første niveau således som aktionsforskning med overvejelser omkring dens politisk-praktiske effekter, mens debat arenaen hedder 'sikkerhedsbegrebets udvidelse', for det var 'terms of agreement' for samarbejdet. På det andet niveau er sikkerhedsliggørelsesteori selve fokusset, og vi vil her vurdere, hvad teorien magter analytisk og praktisk, og om udfordringerne er generelle, specifikt ikke-vestlige eller skyldes den revolutionære situation. Dermed optræder to væsentlige skift, når vi bevæger os mellem artiklens lag: Emnet er sikkerhedsbegrebet på det ene, sikkerhedsliggørelsesteori på det andet; og formen er rapporterende på det første niveau for at etablere konferenceforløbet som empiri, mens det andet niveau udfoldes analytisk som et spørgsmål om teoriens rækkevidde og revisionsbehov (se Fig.1). Ideelt set kunne inddrages (og indtegnes) et 3. lag, idet vi trækker på dels videnskabsfilosofi som vejledning i hvordan teoriers rækkevidde vurderes, dels postkolonial teori omkring vestlige teoriers rejser i den tredje verden. I denne korte artikel må disse kilder forblive overvejende implicitte.

\section{Stater, mennesker og regimer i arabisk sikkerhedstænkning}

Idéen til at forholde sig til udvikling i Mellemøsten ved at fokusere på utraditionelle sikkerhedsbegreber og -trusler voksede, som nævnt, ud af Arab Human Development rapporten fra 2009. Rapporterne vakte fra første udgivelse stor opsigt, fordi de var uvanligt frimodige i arabisk (selv-)kritik af landenes eget ansvar for at sakke stadig mere bagud internationalt mht. udvikling, forskning med meget mere - frem for at bruge Israel og Vesten som syndebukke. ${ }^{4}$

Det var Human Development-rapporternes grundlægger, Mahbub ul Haq, der i 1994 i UNDP introducerede human security-begrebet, et sikkerhedsbegreb fokuseret på individer i stedet for territorier, udvikling i stedet for forsvar. Den femte af de regionale arabiske human development-rapporter satte i 2009 human security på den lokale dagsorden.

Som i resten af verden, har arabiske sikkerhedsstrategier hvilet på top-down-sikkerhedsopfattelser om militære trusler mod staten, udefrakommende trusler fra andre magter. Denne tilgang sætter statens militære sikkerhed højest på behovspyramiden, og sikkerhed ses som en sikring af 'indenfor' mod 'udenfor' ud fra den traditionalistiske idé om at

„threats arising from outside a state are somehow more dangerous to its security than threats that arise within it" (Ullman 1983, 133).

Som især RBJ Walker (1993) har tydeliggjort, ligger det dybt i den moderne politiske forståelse, at staten internt ses som en zone af fred og ret (selv hvis der i praksis er 
masser af vold), mens usikkerhed og magtpolitik befinder sig i det internationale rum. Sikkerhedspolitik bliver at sikre staten mod omverdenen. Mohammed Ayoub (1995) påpeger, at $\mathrm{i}$ tredjeverdenslande er truslerne i praksis oftest interne, og det, som Barry Buzan (1983) så som en anomali, at regimet bruger sikkerhedsbegrundelser mod sin egen befolkning, bliver i den tredje verden snarere normen. Så selv om sikkerhedspolitik forbliver rubriceret som en del af den internationale politik, bliver omdrejningspunktet regimesikkerhed, hvilket Bahgat Korany et al. (1993) påpegede i en arabisk sammenhæng. Fokusset på statslig, militær sikkerhed kan både overse og forstærke andre civile/sociale/samfundsmæssige sikkerhedsproblemer som $\mathrm{fx}$ ret til ytringsfrihed og religiøs diversitet. $\mathrm{Hx-}$ ren står da både for at sikre landets ydre grænser, og for at kontrollere samfundet langs regimets linjer for, hvilke samfundsgrupper eller aktiviteter som er acceptable, og hvilke som anses som 'trusselsprofiler' (Sayigh 2011). Basale behov som sundhed, arbejde, indflydelse og menneskerettigheder kan være sikkerhedsemner som vægtes højere i befolkningen end regimets sikkerhed, hvad det arabiske forår har været et kraftigt udtryk for.

Med introduktionen i den arabiske verden af begreber som human security, utraditionelle sikkerhedsproblemer og udvidet sikkerhed, opstod to hovedretninger (udover modstandere af udvidelse). Én retning forsøger at udvide sikkerhedsbegrebet som en måde at give staten større greb om mere af samfundet, mens en anden forsøger at brede sikkerheden ud med en større rolle for ikke-statslige aktører. Den første følger den egentligt nærliggende logik, at hvis nye trusler presser sig på, må de behandles på samme måde og gerne af de sædvanlige specialiserede instanser (militær, sikkerhedsapparat, osv.). Det er netop det scenarie, sikkerhedsliggørelsesteorien advarer imod. Ikke at det aldrig kan komme på tale at sikkerhedsliggøre nye trusler eller give officielle aktører nye kompetencer - man skal bare være klar over, hvilken pris dette har blandt andet i form af magtkoncentration og afpolitisering; og at der ikke er tale om en automatisk, nødvendig og uskyldig reaktion på objektive sikkerhedsproblemer. Den anden tendens peger på, at de nye problemer har en karakter, der gør at kompetente løsninger må udspringe af en bredere vifte af aktører. Særligt i Arab Human Developmentrapporten udpeges manglende politiske reformer i de arabiske lande til kilden til økonomisk og social stagnation; sikkerhedsproblemer forværres, så længe reformer udebliver. Set med sikkerhedsliggørelsesteoriens øjne, er denne anden strategi umiddelbart mere attraktiv, idet den politiserer og demokratiserer, men den rummer også den principielle risiko, at decentralisering af sikkerhedens subjekter opløser den makrohistoriske pacificering, den moderne stat udførte ved at monopolisere sikkerheden
(Walker 1997; Williams 1998), og risikoen vokser for intern politisk vold, hvis flere aktører får autoritet til at afgøre spørgsmål om overlevelse og undtagelser.

Den stærkeste sikkerhedsteoretiske røst for den anden tendens er sandsynligvis Bahgat Korany, som skelner kritisk mellem stats-sikkerhed og social-sikkerhed (Korany 1994, 173; 2011). Denne kritiske retning søger at korrigere arabiske regeringers sikkerhedspolitiske fokus ved at rette blikket mod utraditionelle 5 sikkerhedstrusler som fx klimaforandringer, epidemier, organiseret kriminalitet og massemigration (Jacoby \& Sasley 2002; Korany 1994). Disse har det til fælles, at de ikke er entydigt forbundet til en statsaktør, at de ikke er af militær natur, og de kræver en koordineret indsats fra forskellige sektorer og lande. En sådan disallokering af store spørgsmål væk fra staterne og i retning af dels individet, dels en større transnational aggregering vil $\mathrm{i}$ en arabisk sammenhæng nærliggende konvergere med en form for panarabisme. Denne udvidende tendens er dog stadig forholdsvist ny, og arabiske akademikere såvel som policy-makers debatterer stadig, hvordan 'arabisk sikkerhed' bør forstås. Kritikere blandt egyptiske samfundsteoretikere ser panarabismen som er et emotionelt projekt, staternes suverænitet vil spænde ben for (Barnett 1998).

Kritisk sikkerhedsteori trives mest i Vesten og især Europa, mens den traditionelle sikkerhedsteori dominerer i det meste af verden inklusiv Mellemøsten, hvor nyere historie byder på interne krige, eksterne invasioner samt interne og eksterne magtalliancer som blandt andet holder hinandens atomare projekter i skak og traditionel sikkerhedstænkning relevant (Bilgin 2004; Ayoob 1995; Buzan \& Wæver 2003). Mange international politikforskere konkluderer, at nyere sikkerhedsbegreber som human security og miljøsikkerhed realpolitisk indtager en sekundær position, rangeret efter militær sikkerhed. Traditionel sikkerhed bliver set som en nødvendighed for at opretholde eksistensen, mens nyere sikkerhedsemner er 'tilvalgs'-emner, man kan håndtere alt efter overskud og kapacitet, såfremt den traditionelle top-down-sikkerhed er på plads. ${ }^{6}$

I samfund med en stærk stats- og militærelite vil nye trusler typisk fremstå som udtryk for en 'uregerlighedskrise'. For eksempel var den panik, der i 2009 opstod i Egypten omkring svineinfluenza, en begrundelse for vores partneres interesse for hele projektet. At denne sygdom generelt ikke udviklede sig til den frygtede pandemi, opfattes som en generel overreaktion i det meste af verden, men i Egypten gik sagen særligt skævt, da man dræbte stort set alle landets svin, med knusende effekt for landets koptiske minoritet for hvem svineproduktion var vigtig. Selv om sygdommen oprindeligt kom fra svin, bestod dens farlige fase i smitte menneske-til-menneske, 
og der havde været væsentligt mere omkostningsbevidste måder at håndtere truslen på. Vores egyptiske samarbejdspartnere så sagen som et udtryk for, hvordan nye trusler var sværere at styre end traditionelle, fordi befolkningen og pressen også blev aktører. De så et behov for styrket statslig kapacitet til krisehåndtering og risikokommunikation.

Sikkerhedsliggørelsesteorien efterlyser evaluering af de praktisk-politiske implikationer af forskellige former for udvidelse. Projektets formål er ikke at argumentere for en sikkerhedsliggørelse af disse emner, men at bistå under den igangværende åbning af den mellemøstlige sikkerhedspolitiske dagsorden for utraditionelle sikkerhedsproblematikker og skabe størst mulig bevidsthed om de politiske valg, der måske ellers let kunne blive camoufleret som tekniske spørgsmål om tilpasning til 'nye trusler'.

\section{Fra København til Kairo}

For at kortlægge erfaringerne fra mødet mellem sikkerhedsteorien og den mellemøstlige situation, vil vi her gennemgå debatterne på projektets konferencer både før og efter revolutionen. Herfra følger betragtninger om, hvordan det opleves fra teoriens side at tage part i diskussionerne i Kairo, og iagttagelserne tjener også som udgangspunkt for et Københavnerskole-blik på revolutionen. Konklusionen vil diskutere, hvordan disse betragtninger leder til nye perspektiver for Københavnerskolen.

Helt konkret består samarbejdet af fire mindre workshops i København og Kairo samt en sammenfattende konference i Kairo efterfulgt af et arabisk policyskrift og en antologi i både arabisksproget og engelsksproget udgave. Emnerne for de fire workshops var: konceptuelle og teoretiske spørgsmål (København juni 2010); Miljøtrusler: epidemier, katastrofer og klimaforandringer (København oktober 2010); Migration (Kairo november 2010); og politiske og samfundsmæssige konflikter (Kairo december 2010). Den endelige konference fandt sted i Kairo i juni 2011. Publikationerne er under udarbejdelse.

Samarbejdet mellem København og Kairo var et møde mellem danskernes relativt abstrakte tilgang til utraditionelle (og traditionelle) sikkerhedstrusler og den arabiske kontekst, som ACPSS er en autoritet på. Den umiddelbare udfordring var at afklare, hvilke trusselsområder det var relevant at fokusere på og hvordan. CAST lagde i samarbejdet særlig vægt på implikationerne af at definere et emne inden for enten den normalt-politiske eller en sikkerhedsmæssig ramme, mens flere af vores egyptiske partnere vægtede, at de traditionelle trusler også kom med ind i rammen. De to ønsker var forenelige. Vanskeligere var at tilgodese både top-down og bottom-up (jf. forrige afsnit om de to udvidelsesdagsordner), og det måtte eksplicit forhandles som en aftale, at ethvert emne skulle ses fra begge vinkler.

Udover Danmark-Egypten forsøgte vi at facilitere møder mellem: teoretikere og praktikere, og - mindre i øjnefaldende, men altafgørende - sikkerhedsforskere og 'emne'specialister. Et projekt, hvor man udvider til at inddrage eksempelvis 'klima' som sikkerhedsemne, rummer en risiko for, at man enten blot holder en konference, hvor 'klimaeksperter' siger det, de plejer at gøre - nu blot med den for dem selv overraskende status, at det er blevet sikkerhedspolitik; eller sikkerhedseksperter kloger sig på et nyt emne, de ikke har forstand på. Et succeskriterium var at få sikkerhedseksperter og emneeksperter til at samarbejde konkret med fokus på, hvilken forskel det vil gøre $i$ håndteringen af hvilke specifikke udfordringer, hvis de behandles eller ikke behandles som sikkerhed.

Vanskeligheden blev tydelig på miljøworkshoppen, da Charlotte Tamason og Peter Kjær Mackie Jensen fokuserede på vandkvalitet fremfor som oftest spørgsmålet om kvantitet og potentielle konflikter over fordelingen af vand mellem Nil-landene. Den fælles interesse i kvalitet kunne danne grundlag for regional regulering af industriel brug af floden, og kvaliteten af flodvandet, som bruges til landbrug, burde kvalitetssikres. Men selv om de egyptiske kommentarer anerkendte behovet for rent Nilvand, argumenterede de, at behovet for at sikre kvantitet frem for kvalitet var større og mere akut. Det blev fremført, at Egypten er et af de større landbrugslande i Mellemøsten og økonomisk afhængig af Nilens fortsatte vandressourcer, og klimaforandringers forøgelse af svindet sås som en større trussel end vandkvaliteten. Stigende priser på fødevarer som hvede kan skabe social uro, som det sås, da stigende brødpriser var blandt årsagerne til de folkelige protester i Tunesien, som startede det arabiske forår. Den egyptiske side fokuserede på, hvordan en 'utraditionel' trussel kan antage 'traditionel' karakter, hvilket illustrerede vanskelighederne dels ved at forene emneekspertise med sikkerhedsekspertise, dels hvordan 'utraditionelle trusler' når alt kom til alt blev trumfet af 'højere nødvendigheder' fra traditionelle trusler, hvor det dog var bemærkelsesværdigt, at et af de mest traditionelle sikkerhedshensyn fra egyptisk side var - vand.

Skismaet gik ikke konsekvent mellem danske og egyptiske deltagere, men ofte sikkerhedseksperter ift. emneeksperter. Det sås i diskussionen som fulgte Peter Seebergs præsentation om, hvor forskelligt massemigration opfattes i EU og i Mellemøsten. Han anførte, at emnet var blevet sikkerhedsliggjort af EU i forhold til samarbejde med Mellemøsten, især for de sydeuropæiske lande. Egyptiske deltagere anerkendte, at der var reelle sikkerhedsmæssige bekymringer for EU, men argumenterede, at den europæiske højreekstremismes sikkerhedslig- 
gørende diskurs hæmmer EU i at være en del af løsningen frem for af problemet. De egentlige sikkerhedspolitiske eksperter fokuserede på den internationale relation (Nordafrika-EU), og de tematiske migrationseksperter havde svært ved at vinde gehør hos sikkerhedseksperterne mht. migrationens relevans som sikkerhedsemne per se.

Den største udfordring vedblev dog at være samtænkningen af top-down og bottom-up. Ekspert i flygtningestrømme Ayman Zohry fremlagde et overblik over, hvordan Egypten fungerer som et samlingspunkt for mange af regionens flygtningestrømme fra Mellemøsten og afrikanske lande, hvilket fører til interne konflikter og kamp over ressourcer, forhøjet kriminalitet og marginaliserede og isolerede samfund. Sine Tarby introducerede derimod et fokus på flygtninges forhold, både under flugten og risikoen for at leve et helt liv i flygtningelejre uden borgerrettigheder og adgang til basale nødvendigheder som mad, vand, skolegang, retssikkerhed og lægehjælp. At flygte fra usikkerhed bringer altså ikke nødvendigvis sikkerhed med sig, hverken for de som flygter eller hvor der flygtes til, hvilket understregede de politiske implikationer af spørgsmålet om, hvem der definerer sikkerhedstruslerne: 'sikkerhed for hvem'?

På næste workshop holdt daværende politigeneral Serag el-Rouby, tidligere leder af egyptisk Interpol, et bemærkelsesværdigt oplæg. Han gennemgik detaljeret former for organiseret kriminalitet, og hvor lette eller svære de var at modvirke. Der bredte sig en trykket stemning i lokalet, da han omtalte de effektive men hårdhændede metoder, der fandt anvendelse. Det lykkedes ikke at få ham til at forholde sig til, om særlige grænser definerer dele af dette felt som egentlige sikkerhedstrusler og andet som 'normal' kriminalitet, og hvilken forskel dette ville gøre. Danske bidrag til debatten omhandlede inddragelse af civilsamfundet $i$ at håndtere denne slags trusler mod samfundets stabilitet, og hvordan man sikrer individuelle rettigheder i processen - her med anvendelse af danske erfaringer, hvor især terrorpakkerne har skabt debat.

På samme konference om politiske og samfundsmæssige konflikter diskuterede Morten Valbjørn hvilket 'andet nyt Mellemøsten', der tegner sig, når vi nu ikke får Bush-administrationens lovede 'nye Mellemøsten'. Debatten kom fordomsfrit rundt om mangfoldige religiøse og politiske strømninger i forskellige dele af Mellemøsten, som skulle vise sig mere relevant, end vi var bevidste om på det tidspunkt. På trods af at vi var midt mellem første og anden valgrunde af det egyptiske parlamentsvalg og havde læst om mindre protester i gaderne, var der ingen under denne konference, som forudså den revolution, der ventede lige rundt om hjørnet. Selv de deltagere, der helt privat og uden for de officielle diskussioner - havde størst samfundskritisk engagement, fremførte, at de unge var færdige med at tro på 'den store politik' og reformer af samfundet som sådan - i bedste fald var der ved at åbne sig bedre muligheder for 'den lille politik' i lokale institutioner og boligområder. Generelle angreb på regimet var blevet meningsløse.

Samlet gav den første runde af møder følgende resultater ift. vores tre typer spørgsmål:

1. Vores rolle: Vi havde ventet én og fik to. Ventet var, at vi skulle have en slags metafunktion: svarende til Københavnerskolens status af metarefleksion på udvidelser, skulle vi styrke refleksiviteten hos deltagerne omkring de politiske handlinger, det ville være at (af)sikkerhedsliggøre emner - hvorledes tilsyneladende analytiske diskussioner af, hvad der 'er' sikkerhedstrusler reelt handler om forskellige måder at regulere deres håndtering. Men derudover fik vi en mere direkte 'advocacy'-funktion som stedfortræder for 'nedefra'perspektivet, fordi den 'fløj' ikke var vel repræsenteret i de første runder. 'Aktionsforskningen' blev lidt mere direkte aktør, end det var tilsigtet.

2. Analyse af udvidelsens politik og dermed sikkerhedsliggorelsernes mønstre: De konkrete debatter emne for emne afspejlede jævnligt et mønster, hvor fremtrædende sikkerhedseksperter ønsker en top-down udvidelse, der vil styrke statens greb om nye emner; var mindre optaget af at skabe rum for nye aktører; og helst reserverede ny sikkerhedstænkning til supplerende trusler, mens de klassiske forblev uantastede. Deltagerobservation af udvidelsens politik skabte en sikkerhedsliggørelsesanalyse af en markant establishmentstrategi - og noget mere vaklende, opførte vi en konstellation med en modstående nedefra-op udvidelse, som vi mente at have fremanalyseret uden for konferencerne men ofte selv måtte repræsentere i forløbet.

3. Teoretiske udfordringer: Der var ikke umiddelbart problemer med at bruge teoriens termer på den arabiske situation, og fagdebatternes forventede 'ikke-vestlige' vanskeligheder meldte sig i hvert fald ikke, hvor de var annonceret. En operationel vanskelighed i projektet kunne have en teoretisk pendant: De to slags eksperter, sikkerhedens og emnernes. Det ligger smukt for CAST's fokus på discipliners og praksisfelters forskellige rationaliteter, ${ }^{7}$ men sikkerhedsliggørelsesteori antager, at de tekniske eksperter understøtter politiske dagsordener; som de ikke rigtigt gjorde på vores konferencer. Er der måske endda en særlig ikke-vestlig vinkel her? Vi vender tilbage til dette i næste afsnit.

\section{Fra Kairo til Kairo - revolutioner kan gøre en forskel}

Siden disse konferencer var tusinder af demonstranter strømmet ud i gaderne i store dele af den arabiske ver- 
den - i overvældende antal i Egypten - med krav om, at regimerne skulle væltes, og styreformen ændres substantielt.

Utraditionelle sikkerhedstrusler blev både fremhævet og trængt i baggrunden af det arabiske forår. Regimer, som før virkede stabile og stærke, viste sig at kunne væltes af folkeligt pres. Nye magtforhold etableres i øjeblikket både nationalt og regionalt; sikkerhed for staterne, mellem staterne og for borgerne nyformuleres. I praksis er et bredere sikkerhedsperspektiv i spil, fordi civile organisationer udøver indflydelse. Det tidligere sikkerhedsfokus på den personificerede centrale magt bliver formodentlig mindre fremtrædende, når den politiske orden omformes, og sikkerhed vil med lidt held blive set som en service, staten udøver for sin befolkning frem for sig selv. Om forandringerne så fører til en reel indsats over for utraditionelle sikkerhedstrusler, som påvirker samfundslag og grupper uden for eliten, afhænger nu af politisk fokus og vedholdenhed. Et af sikkerhedsteoriernes centrale spørgsmål: 'sikkerhed for hvem?' er stadig relevant efter det arabiske forår.

$\mathrm{Vi}$ vendte tilbage til den afsluttende konference i Kairo i juni 2011. Denne konference skulle samle op på de tematiske konferencer og dels bringe bidragsyderne sammen for at udforske sammenhænge, dels inddrage bredere kredse af 'interessenter' i Egypten, hvilket nu inkluderede Sjette April Bevægelsen og Det Muslimske Broderskab såvel som repræsentanter fra civilsamfunds organisationer og medieinstitutioner.

Særligt ét indlæg udløste i kølvandet på den nylige og fortsatte revolution en diskussion, som fik konferencesalen til at koge og simultantolkene på hårdt arbejde. Det drejede sig endnu en gang om daværende politigeneral Serag el-Roubys oplæg. Denne gang blev generalens præsentation hurtigt afbrudt af stemmer blandt tilhørerne, som vendte hans argumentation på hovedet og anklagede politiet for at være Egyptens bedste eksempel på organiseret vold. Tilhørere henviste både til den ordinære egyptiske politistyrke (al-shurta) styret af indenrigsministeriet og baltagiya'erne, en uorganiseret gruppe bestående af bandemedlemmer og kriminelle informanter, hvervet af politiet til at løse de mere hårdhændede opgaver som fx at nedkæmpe demonstranter. Debatten satte problematikken om legitimt monopol på vold på spidsen, og argumenterne fra salen var vel at mærke ikke ensidige: Adskillige tilhørere mente, at politiet havde enhver ret til at nedkæmpe uromagere, mens andre udtrykte, at netop politiets brutale nedkæmpelse af de tidlige protester havde fået dem selv på gaderne. Sidstnævnte folk udråbte militæret som revolutionens sejrherrer, fordi de tidligt i processen havde valgt at sende politiet hjem og støtte de demonstrerende.
Både fra denne debat og i samtaler med folk uden for programmet, tegnede sig et billede af nye dominerende mønstre:

For samarbejdets spørgsmål om udviklingen af sikkerhedsbegrebet i Mellemøsten kunne vi for det første konstatere, at der (i hvert fald på overfladen) var større enighed om 'det brede sikkerhedsbegreb' - inklusive det kontroversielle aspekt om flere legitime sikkerhedsaktører. Forskere, der i de tidligere runder havde fremtrådt som tilbageholdende mht. nye opfattelser, var nu langt mere åbne for nye tanker og for en reel rolle til ikkestatslige aktører.

For det andet, set med Københavnerskolens teoretiske blik var den polarisering, der toppede med skænderiet under politigeneralens foredrag, sandsynligvis repræsentativ for nye mønstre, hvor utraditionelle trusler var kernen - men måske i sidste ende blev ultratraditionelle:

- Hos aktivisterne trives en fristelse til at sikkerhedsliggøre alt som 'kontra-revolutionært'. Den slags sikkerhedspolitisk forsvar for 'revolutionen' mod truslen fra det gamle regime kan på den ene side være yderst forståeligt i den aktuelle situation i Egypten, på den anden side er det et farligt kort, der let kan bruges til at delegitimere først det egentlige establishment og siden flere og flere politiske modstandere - som set $\mathrm{i}$ de franske og russiske revolution og måske tydeligst $\mathrm{i}$ Cubas definition af trusler mod 'revolutionen' årtier efter (Holbraad \& Petersen 2012).

- En modsatrettet sikkerhedsliggørelse florerer hos mere traditionelle kredse - både eliter med interesser i l'ancien regime og svage grupper, der dels mærker økonomiske og tryghedsmæssige udfordringer først, dels er åbne for mediepåvirkning. Først var 'kaos' den nye trussel - lovløshed og de økonomiske tab ved den politiske ustabilitet - og deraf følgende krav om lov og orden. I næste omgang har regimet og pressen i stigende grad forsøgt at antyde ret diffuse trusler fra fremmede magter, som folk forventes at høre som Vesten og Israel. De trusler trækker på utraditionelle elementer, men de er naturligvis hyper-traditionelle.

Opgaven teoretisk og praktisk kan i denne situation meget vel være en form for 'afspænding' mellem de to, at undgå de eskalerer til en krise, der stopper reformprocessen. Det kan nok mest effektivt gøres ved at kanalisere de unge revolutionæres regimekritik over i konkrete klager over politivold og krav om reform af sikkerhedssektoren, fordi det fra andre samfundsvinkler kan ses som en form for øget institutionsbygning og dermed stabilitet i modsætning til yderligere destabilisering af samfundet.

En ustabil revolutionær situation som den egyptiske kan tilnærme sig ekstremet, hvor den ene part forsvarer 
forandring som sådan, og modparten gør stabilitet til målsætningen. Denne modstilling er naturligvis en dimension af politik i nærmest alle samfund. Men hvad sker der, når de abstraheres til poler, der derefter forsvares mod hver deres fjender?

En relevant opgave for teorien, hvor den gennem sin analytiske styrke kan have politisk effekt, kunne være at konstituere det institutionelle omdrejningspunkt, der skal forsvares for at sikre en stabilitet, der tillader forandringer. Dette peger tilbage på afspændingspolitikkens klassiske paradokser: Dels om at forandring kun er mulig ved så meget stabilitet, at den totale ændring er udelukket, og dels den klassiske konservative indsigt, at man kun kan bevare ved at ændre (Wæver 1989). Dette betyder sandsynligvis i den konkrete situation sikkerhedssektorreform (politibrutalitet som procedureproblem) og konstitutionel politik. Kan man skabe en sikkerhedspolitik for det politiske balancepunkt, som en ustabil situation vipper hen over? Hvis dette først er udfoldet, vil det givetvis vise sig, at det er alt andet end en lokal indsigt af relevans kun for 'eksotiske' cases langt hjemmefra. Tværtimod kan det blive et afgørende moment i teoriens generelle udvikling.

Revolutionen rammer to bløde punkter i teorien. Teorien kritiseres ofte for at være for Schmittiansk; her er den det måske ikke nok. Carl Schmitts berygtede politikforståelse fokuserer på den generelle undtagelsestilstand, hvor hele samfundet genfunderes. Sikkerhedsliggørelsesteori handler om afgrænsede undtagelser: I en orden der ikke generelt anfægtes, argumenteres for undtagelse på et konkret felt. Derfor er teorien distinkt fra Schmitts. Men hvad hvis situationen bliver Schmittiansk - åben for at en ny ordensinstallerende aktør, der generaliserer undtagelsen; falder den situation uden for teoriens rækkevidde? For det andet er teoriens politikbegreb spændt ud mellem Schmittianske (anti)politiske undtagelser og Arendt'sk samskabelse, men de to modstandere er fælles om at underprioritere institutioner (Buzan et al. 1998, 141ff; Gad \& Petersen 2011). Så hvordan analyseres situationer med institutionalisering som åbent spørgsmål? Når den teoretiske udfordring her bliver særligt tydelig - og måske løsningen særligt produktiv - skyldes det ikke, at casen er ikke-vestligt, men den revolutionære situation.

Hvad er der imens sket med de mere 'tekniske' utraditionelle trusler - de der ikke er direkte koblet til den styrende politiske konstellation? Er de påvirket af den ændrede politiske situation? Et eksempel kunne være vand, som denne artikels forfattere præsenterede ved den afsluttende konference. På baggrund af diskussionen på den tematiske workshop kom Nilen ind i en Københavnerskoleramme: Reelt har nødvendigheden af vand fra Nilen altid været defineret som sikkerhed i teoriens forstand, for det har været set som afgørende for Egyptens overlevelse. Allerede 400 f.Kr. skrev Herodot, at 'Egypten er Nilens gave', dvs. at landet er helt afhængigt af floden, ligesom der er rigeligt med citater fra nyere ledere om, at alle midler vil blive brugt til sikring af en tilstrækkelig del af Nil bassinets vandressourcer. Paradokset er imidlertid, at man tidligere ikke brugte selve ordet 'sikkerhed' og dermed ikke gjorde det helt tydeligt, hvordan vandspørgsmålet var helt oppe at ringe i udenrigspolitisk sammenhæng. Det blev imidlertid muligt som udløber af det udvidede sikkerhedsbegrebs internationale gennemslag, og de sidste ti år trængte begrebet 'vandsikkerhed' ind i analyser af Nilspørgsmålet, hvor det ofte legitimerer egyptisk blokering af forhandlede løsninger (Mekonnen 2011). Dette er paradoksalt, for i samme periode er det blevet stadig mindre sandt, at Egypten er eneafhængig af Nilen (der foregår indirekte vandimport i produkter, og en stadig større del af vandet går til industri og ikke landbrug eller husholdninger). De internationale klimaforandringer truer med at forværre vandsituationen (AlMarashi 2011), så valget hedder ikke 'ikke-sikkerhedsliggjort vs. nationalt sikkerhedsliggjort', men må inddrage som tredje mulighed en falles sikkerhedsliggørelse som vejen til et vandregime for Nilen som sikkerhedspolitik, netop i lyset af klimatruslerne.

Et er, at denne analyse var vores 'fordøjelse' af input fra teoretikere og praktikere undervejs i processen, noget andet var, om denne vinkel nu stod bedre, dårligere eller anderledes i lyset af revolutionen. Det meget foreløbige billede var, at de nye røster ikke var nået frem til at interessere sig for den slags 'fjerne' emner, så den gamle tilgang dominerede stadig, og man var utilbøjelig til at lade 'nye sikkerhedsbegreber' betyde, at man skulle ændre politik på et så centralt område som vand. Forventningen var tydeligvis stadig, at ny sikkerhed skulle lægge sig udenom eller ovenpå 'gammel sikkerhed', som der helst skulle pilles mindst muligt ved. Hvis de politiske omvæltninger i Egypten skal føre til bevægelse i retning af mere åbenhed for 'ny sikkerhedspolitik', kan det både hjælpes på vej af personændringer fra klassisk sikkerhedselite til nye folk, men også og måske mere sandsynligt af de nye strategiske vilkår for Egypten, efterhånden som revolutionens effekter ændrer forholdet til Israel og USA og dermed måske nødvendiggør mere fleksibel politik overfor de vestlige og sydlige naboer.

Afkoblingen mellem tekniske specialister og sikkerhedseksperter var om muligt mere påfaldende end på de tidligere møder. Dette problem for teorien kan afspejle en af de ikke-vestlige pointer: at staten ikke gennemtrænger samfundet så homogent og konsekvent som i vestlige samfund (Curley \& Siu-lun 2008). Interaktionskapaciteten er lavere, og subsystemer kobles ikke tæt nok til at fremtvinge konsistens inden for reelt allierede aktører. Dette svarer til den generelle postkoloniale pointe, at vi 
bruger ord som 'stat', 'suverænitet' og 'politik' på forhold uden for Vesten, der ikke svarer til Vestens forestillinger om de begreber, fordi vejen-ad-hvilken de kom dertil er så anderledes (Chatterjee 2004).

Kairo-efter-revolutionen opdaterede vores konklusioner:

1. Vores rolle - blev meget lille, da udviklingen kom op i de høje omdrejninger.

2. Analyse af udvidelsens politik og dermed sikkerhedsliggørelsernes mønstre: Kampene på konferencen leverer igen empiri til en teoretisk analyse, hvor en klar konstellation tegner sig. Nu er de to fløje (som nok ikke er meget forskelligt bemandet fra sidst) konstitueret omkring nye spørgsmål: forsvar for revolutionens foranderlighed vs. forsvar af orden mod anarki indefra og tågede trusler udefra.

3. Teoretiske udfordringer: To problemer for teorien er trådt i forgrunden. Den markante afkobling mellem sikkerhedseksperter og tekniske specialister afspejler muligvis ikke-vestlige vilkår; og den revolutionære situation udfordrer teoriens politikbegreb, der måske forudsætter en underliggende stabilitet som ramme om undtagelsens begrænsede overskridelse.

\section{Hjem fra Kairo til København}

Det er velkendt fra postkoloniale studier, at en teori ikke bare overføres fra 'oprindelsesland' til nye miljøer. Edward Said skrev i et berømt essay, Travelling Theory (1983), at der typisk opstår nye former af teorien, der hverken er slavisk kopiering eller 'kreativ misforståelse'. I en anden situation udvikles teorien til at blive noget andet og dér mere relevant. Ingen teori er komplet eller lukket, så den rummer muligheder, der ikke ville være korrekte eller nærliggende i den oprindelige situation, men omvendt heller ikke ville optræde i den nye kontekst uden både lokal indsats og teoriens bidrag.

Hvis teorien rejser hjem igen, hvad tager den så med tilbage? Vi har undersøgt tre typer af spørgsmål:

1. Hvordan var det at være deltager - en særlig slags ydre medspiller? Før revolutionen blev det mere vidtgående, end vi ønskede, fordi metafunktionen med refleksion over egne handlinger blev suppleret af en slags stedfortræderstemme for de establishmentfjerne røster, det var svært at få med på møderne. Efter revolutionen blev intensiteten lokalt så høj, at vores rolle blev marginal. Selve den oplagte ide at fungere som metarefleksion, en evigt politiserende samvittighed, der flytter sikkerhedsargumenter fra teknisk nødvendighed til politiske valg, fungerede rimeligt godt i den første fase, men blev meget krævende $\mathrm{i}$ anden fase. Tredje fase bliver spændende: publikationerne!
2. Udvidelsens sikkerhedsspil varierer mellem regioner så hvad er den arabiske variant? Eller hvad bliver den? I fasen frem til revolutionerne var vores tolkning - som vi også tilrettelagde projektet ud fra - at to forskellige udvidelsesidéer konkurrerede: en der ønskede at udvide for at skabe mere rum for almindelige menneskers human security, for flere aktører fra civilsamfundet, og en anden der så nye trusler som anledning til at udvide den eksisterende sikkerhedselites greb om flere sager i samfundet. En særligt sofistikeret udgave af human security varianten gjorde selve regime-rigiditeten til den ultimative trussel - kun politiske reformer kunne i sidste ende løse samfundets interne og eksterne udfordringer. Der er en vis kontinuitet mellem denne og en af den 'sen-revolutionære' periodes diskurser, idet aktivisterne i dag udpeger fortsættelsen af regimets personer på magtfulde positioner som den største trussel. Mere konservative kræfter kombinerer i dag individbekymringer (økonomi, ro og orden) med diffuse ydre trusler - i princippet relativt traditionel sikkerhed, men i den konkrete sammenhæng skal de løftes frem til eksistentiel undtagelsesstatus, så sikkerhedsliggørelsesanalyse har let ved at se de aktive talehandlinger også her.

3. Teorien selv er blevet udfordret på især to punkter. Den mildt sagt løse kobling mellem tekniske eksperter, sikkerhedseksperter og politiske aktører bør studeres nærmere, særligt for at afklare om vestlige samfund er strammere koblede og derfor giver vestlige teorier et skævt blik på disse debatter. Politikforståelsen i sikkerhedsliggørelsesteori blev udfordret, ikke af Mellemøsten, men af revolutionen. Teorien antager en grundlæggende stabilitet som ramme om mulige emnespecifikke undtagelser, men hvis hele situationen bliver én stor undtagelse, skal teorien til at tematisere sikkerhedspolitik i form af skabelse af institutionelle ankre. Den aktuelle trekant af militær, aktivister og det Muslimske Broderskab frister til det klassiske mønster, hvor to parter udnævner den tredje til statsfjende. Særligt i Egypten, hvor omgangen med sikkerhedsstrukturerne - hær og politi - er omdrejningspunkter for det politiske liv, kan en vellykket sikkerhedsliggørelse for en dynamisk institutionalisering blive afgørende for at undgå en intern sikkerhedspolitisk eskalering, der vil koste dyrt på demokratikontoen.

Hvis dén udfordring håndteres i det egyptiske projekt, vil den generelle teori være i gang med en markant udvikling af sit politikbegreb, der har konsekvenser for, hvordan også vores eget samfund skal analyseres - og måske også ageres på. 


\section{Litteratur}

Al-Marashi, I 2011, 'Egypt', i D Moran (red.), Climate Change and National Security: A Country-Level Analysis, Georgetown University Press, Washington.

Ayoob, M 1995, The Third World Security Predicament: State Making, Regional Conflict and the International System, Lynne Rienner, London.

Barnett, MN 1998, Dialogues in Arab Politics: Negotiations in Regional Order, Columbia University Press, New York.

Bilgin, P 2000, 'Inventing Middle Easts? The Making of Regions Through Security Discourses', i BU Utvik \& KS Vikør (red.), The Middle East in a Globalised World, Nordic Society for Middle Eastern Studies, Bergen.

Bilgin, P 2004, "Whose 'Middle East'? Geopolitical Inventions and Practices of Security', International Relations, vol. 18, no.1, pp. 2541.

Bilgin, P 2011, 'The politics of studying securitization? The Copenhagen School in Turkey', Security Dialogue, vol. 42, no. 4-5, pp. 399-412.

Buzan, B 1983, People, States, and Fear: The National Security Problem in International Relations, Wheatsheaf Books, Brighton.

Buzan, B, O Wæver \& J. de Wilde 1998, Security: A new Framework for Analysis, Lynne Rienner, London.

Buzan, B \& O Wæver 2003, Regions and Powers: The Structure of International Security, Cambridge University Press, Cambridge.

Chatterjee, P 2004, The Politics of the Governed: Reflections on Popular Politics in Most of the World, Permanent Black, Delhi.

Curley, GM \& W Siu-lun (red.) 2008, Security and Migration in Asia: The Dynamics of Securitization, Routledge, London.

Gad, UP \& KL Petersen (red.) 2011, 'Politics of Securitization', særnummer af Security Dialogue, vol. 42, no. 4-5.

Holbraad, SM \& MA Petersen 2012, 'Revolutionizing securitization: an anthropological extension of securitization theory', International Theory, under udgivelse.

Hudson MC (red.) 1999, The Middle East Dilemma: The Politics and Economics of Arab Integration, Columbia University Press, New York.

Ibrahim, SA 1996, 'Future Visions of the Arab Middle East', Security Dialogue, vol. 27, no. 4, pp. 425-436.

Jacoby, TA \& BE Sasley (red.) 2002, Redefining Security in the Middle East, New Approaches to Conflict Analysis, Manchester University Press, Manchester.

Korany, B, P Noble \& R Brynen (red.) 1993, The Many Faces of National Security in the Arab World, St. Martin's Press, New York.

Korany, B 1994, 'National Security in the Arab World: The Persistence of Dualism', i D Tschirgi (red.), The Arab World Today, Westview Press, Boulder.

Korany, B 2011, hovedtale ved DEDI/CAST/ACPSS-konference i Kairo.

Mekonnen, DZ 2011, 'From tenuous legal arguments to securitization and benefit sharing: hegemonic obstinacy - the stumbling block against resolution of the Nile Waters Question', Mizan Law Review, vol. 4, no. 2, pp. 232-257.

Said, E 1983, The World, the Text and the Critic, Harvard University Press, Cambridge MA.

Sayigh, Y 2011, 'Rethinking the study of middle east militaries', International Journal of Middle East Studies, vol. 43, no. 3, pp. 391-407.

United Nations Development Program, Arab Human Development Report 2009: Challenges to Human Security in the Arab Countries, United Nations Publications, New York; http://www.arab-hdr.org/ publications/other/ahdr/ahdr2009e.pdf

Ullman, R 1983, 'Redefining Security', International Security, vol. 8, no. 1 , pp. $129-153$.
Vuori, JA 2011, How to Do Security with Words: A Grammar of Securitization in the People's Republic of China, ph.d.-afhandling forsvaret i Turku, 2011.

Walker RBJ 1993, Inside/Outside: International Relations as Political Theory, Cambridge University Press, Cambridge.

Walker, RBJ 1997, 'The Subject of Security', i K Krause \& MC Williams (red.), Critical Security Studies, University of Minnesota Press, Minneapolis.

Wilkinson, C 2007, 'The Copenhagen School on Tour in Kyrgyzstan: Is Securitization Theory Useable Outside Europe', Security Dialogue, vol. 38, no.1, pp. 5-25.

Wæver, O 1989, Hele Europa: projekter - kontraster, Det Sikkerheds- og Nedrustningspolitiske Udvalg, København.

Wæver, O 1995, 'Securitization and Desecuritization', i RD Lipschutz (red.), On Security, Columbia University Press, New York.

Wæver, O 2012, 'Aberystwyth, Paris, Copenhagen: The Europeanness of New 'Schools' of Security Theory in an American Field', i AB Tickner \& D Blaney, Thinking the International Differently, Routledge, London.

Wæver, O n.d., 'Security Questions - to widen or not to widen', under udgivelse (skrevet til det Internationale Akademi for Uddannelse og Demokrati's publikation fra DEDI-finansieret, arabisk-dansk demokratisommerskole i 2010).

Williams, MC 1998, 'Modernity, Identity and Security: A Comment on the "Copenhagen Controversy", Review of International Studies, vol. 24, no. 3, pp. 435-439.

\section{Noter}

1 Tak for nyttige kommentarer til medredaktør Morten Valbjørn, tidsskriftets anonyme reviewere og CAST-kollegerne Ulrik Pram Gad, Vibeke Tjalve, Karen Lund Petersen og Peter Marcus Kristensen.

2 Denne kritik findes nok mest tydeligt hos Wilkinson (2007), men også i blandt andet Curley \& Siu-lun (2008). Nyere, mere sofistikerede diskussioner af teoriens begrænsninger og relevans ift. ikke-vestlige cases foreligger hos Bilgin (2011) og Vuori (2011). Betydningen af den europæiske kontekst for 'skolerne', der opstod i Aberystwyth, København og Paris de sidste 20 år, er forsøgt analyseret i Wæver (2012).

3 I praksis er fokus oftere 'mellemøstligt' frem for arabisk, men terminologisk foretrækker mange i Egypten at tale i 'arabiske' termer. Ingen af definitionerne er fyldestgørende, da det arabiske fokus i princippet ser de arabiske staters sikkerhedsemner i relation til hinanden men ikke til Tyrkiet, Iran og Israel, som derfor let kan komme til at fremstå som udefrakommende sikkerhedstrusler. Desuden tager en arabisk sammenfatning ikke højde for den etniske diversitet i regionen. Det mere teknisk regionale fokus, der ligger i betegnelsen 'Mellemøsten', er blevet kritiseret for at være en vestlig konstruktion. I projektet bruger vi begge betegnelser og forsøger at være systematiske mht. at bruge det i den specifikke situation mest passende begreb. For en diskussion af den panarabiske identitetskonstruktion, se Hudson (1999), for en diskussion af den militærstrategiske konstruktion af Mellemøsten, se Bilgin (2000).

4 Rapporterne er udarbejdet af UNDP-Regional Bureau for Arab States i samarbejde både med regeringer og civil samfunds-organisationer, så der er sandsynligvis sket en vis 'clearing' af forfattere, men rapporterne lægger meget vægt på, at de er helt uafhængige, og at bidragsyderne er udvalgt fra toppen af deres felt. Forfatterne er således hverken officielle repræsentanter eller radikal opposition, snarere noget af det nærmeste, man kan komme på uafhængige intellektuelle og eksperter. 
5 Dikotomien traditionel/utraditionel synes den foretrukne i Egypten, og svarer delvist til de dikotomier, der foretrækkes i andre dele af verden: hård/blød, militær/ikke militær, standard/kritisk, snæver/bred, etc. Det er et interessant men til dato lidet udforsket spørgsmål, hvorfor de forskellige terminologier dominerer i hvilke verdensdele.
6 For en mere detaljeret diskussion af fire forskellige mellemøstlige sikkerhedsperspektiver med særskilte prioriteringer af specifikke sikkerhedsemner: et regionalt mellemøstligt, et arabisk-mellemøstligt, et muslimsk-mellemøstligt og et middelhavs-mellemøstligt, se Bilgin (2004) og Ibrahim (1996).

7 Se www.cast.ku.dk 